\title{
Legal Issues Regarding Foreign Investment and the Implementation of the Japan-Indonesia Economic Partnership Agreement
}

\author{
I.B.R. Supancana*
}

The entry into force of the Japan-Indonesia Economic Partnership Agreement on July 1, 2008, is highly expected to boost Japan's investment in Indonesia due to the fact that it is the most comprehensive bilateral agreement between the two countries. The JIEPA covers most areas of economic cooperation, including: taxation, trade in goods, trade in services, movement of natural persons, government procurement, intellectual property, investment etc. Some potential legal issues are anticipated during the implementation of the JIEPA due to some differences between the JIEPA and the Indonesian legal system. This article focuses on issues related to foreign investment related law, namely: instrument of ratification and its legal implications; review mechanism; legal certainty; continuation of business activities; termination of business activities; protection and guarantee of foreign investment such as minimum standard of treatment; investment risks; and disputes settlement mechanism.

\section{Keywords}

JIEPA, Foreign Investment Law, Investment Risks, ICSID, Strategic Investment Action Plan

* Professor of International Law and Investment Law at Atmajaya University, Jakarta. LL.B./LL.M. (Indonesia), Ph.D.(Leiden). He is Chairman/Founder of Center for Regulatory Research in Jakarta. The author may be contacted at: supancana@yahoo.com /Address: Faculty of Law, Atmajaya Catholic University, Jenderal Sudirman 51, Jakarta, 12930, Indonesia. 


\section{Background}

The signing of the historic Japan-Indonesia Economic Partnership Agreement ("JIEPA") marks a new era of economic cooperation between the two countires. JIEPA is the most comprehensive bilateral agreement consisting of 15 chapters with 154 articles. It covers most areas of economic cooperation including foreign investment. JIEPA is equipped with Implementation Agreement and a "Strategic Investment Action Plan."1

With the ratification by the two countries, JIEPA effectively entered into force on July 1 , 2008. Although there is a high expectation that JIEPA would boost Japan's investment in Indonesia, it is also concerned that there might be some constraints on its implementation due to some differences between the JIEPA and Indonesian laws.

This article explores and analyzes foreign investment laws related to the implementation of the JIEPA. The main topics of this paper are as follows:

a. Possible legal constraints on the implementation of JIEPA in relations with existing national laws on investment and other relevant laws;

b. A comparative analysis between existing laws and practice on standards of treatment to investors (both local and foreign), the JIEPA and in relation to international Standard of Treatment;

c. Investment related dispute settlement mechanism in general and as it relates to Foreign Direct Investment in Indonesia ("FDI") in Indonesia, both through adjudication and non adjudication process, including its law enforcement mechanism;

d. Possible commercial and non-commercial risk on FDI in Indonesia; and

e. Some recommendations for implementing the JIEPA.

\section{An Overview of Indonesian Investment Laws and JIEPA's Provisions and Implementing Agreement Related to Foreign Investment}

\section{A. The Existing Conditions of Investment Laws and Policies in Indonesia}

Despite that the Indonesian Government has been working very hard to improve the investment climate through a series of policies and regulatory reforms, ${ }^{2}$ little progress

1 See Implementing Agreement between the Government of the Republic of Indonesia and the Government of Japan pursuant to the Article 13 of the Agreement between Republic of Indonesia and Japan the for an Economic Partnership, Japan-Indonesia, Aug. 20, 2007, available at http://ditjenkpi.depdag.go.id/Website_tr/Preferential\%20Tariff/ IJ-EPA/Implementing\%20Agreement\%20(ID).pdf (last visited on Apr. 4, 2011). The Implementing Agreement with Annexes on Strategic Investment Plan covers: taxation, customs, labor, infrastructure and competitiveness. For a full reference and elaboration, see the Gaikindo website, available at www.gaikindo.or.id (last visited on Apr. 4, 2011).

2 Some policies and regulations reflecting the Government's efforts to improve investment climates are as follows: 
has been made in terms of investment attractiveness and competitiveness compared to other neighboring countries. This condition is partially caused by the poor legal system, high rate of corruption, legal uncertainty and lack of consistency in law enforcement.

Although consistent implementation of JIEPA is a basic requirement for mutual benefits of both Japan and Indonesia, some gaps or constraints are anticipated between provisions of JIEPA and the Indonesian legal system. Foreign investment cases in Indonesia just show the weaknesses on dispute resolution mechanism and its enforcement. ${ }^{3}$ Therefore, Japanese investment in Indonesia will only be improved if the Indonesian Government and stakeholders make a serious commitment to fix these deficiencies.

\section{B. Main Principles and Provisions of JIEPA}

As the most comprehensive bilateral economic agreement between Indonesia and Japan, JIEPA covers very broad aspects of economic ties, including taxation, trade in goods and services, rules of origins, investment, energy and mineral resources, intellectual property rights, government procurement, improvement of business environment and promotion of business confidence, cooperation, dispute settlement, among others. In addition, there are 12 annexes referring to certain chapters and articles. For the implementation of JIEPA, an implementing agreement was concluded with a similar scope of issues. The implementing agreement consists of 8 Chapters and 44 articles with 5 annexes on strategic investment action plan covering tax, customs, labor, infrastructure and competitiveness.

\section{Provisions of JIEPA Related to Foreign Investment}

Specific provisions on investment may be found at Chapter 5 of JIEPA. Basic principles of investment are laid down such as national treatment, most favored nation treatment, general treatment, access to the court of justice, prohibition of performance requirements, expropriation and compensation, protection from strife, transfers, settlement of investment disputes between a party and other party, temporary safeguard measures, etc.

\footnotetext{
Presidential Instruction No. 6 of 2007 concerning Policies on the Acceleration of the Real Sector Development and Empowerment of Micro, Small and Medium-Scale Enterprises; Presidential Instruction No. 3 of 2006 concerning Package of Policy for Investment Climate Improvement. The latest is Presidential Regulation No. 27 of 2009 concerning Integrated One-Stop Services in the Investment Field.

3 Noticeable cases are as follows: Cement Exports from Mexico ("Cemex Case"); Karaha Bodas Corporation Case; Newmont Minahasa Raya case; Aria-West case; and Chung Hwa case. For further analysis of Cemex Case, Karaha Bodas Corporation Case and Newmont Minahasa Raya Case, see I.B.R. SuPAnCANA, KerangKa Hukum dan KeBIJAKAN InveSTASI LANGSUng DI IndONESIA [Legal and Policy Framework of Direct Investment in Indonesia] 144-157 (2006).
} 


\section{Main Principles and Provisions of JIEPA's Implementing Agreement concerning Investment}

Provisions on investment in the implementation agreement of JIEPA are mainly laid down at its 8 annexes concerning the "Strategic Investment Action Plan." The Strategic Investment Action Plan covers some important aspects such as tax, customs, labor, infrastructure, competitiveness, etc. 4

On tax issues, it covers the action plans as follows: establishing and strengthening self-assessment system; reforming VAT for export promotion; protecting taxpayer rights; promoting transparency and disclosure; reducing real business cost; promoting human exchange; and continuing dialogue on tax. 5

With respect to customs, some action plan has been adopted for the purpose of reducing administrative obstacles to speed up the following: customs clearance; improving work ethic; socializing new regulations/laws and their interpretations; implementing an "Electronic Data Interchange" ("EDI") system and on-line official website of Directorate General of Customs and Excise ("DGCE"); enhancing the effectiveness of bonded warehouse; enhancing transparency and fairness; handling other issues indirectly related to custom activities; enhancing transparency and fairness; and increasing. ${ }^{6}$

The labor related provisions address the following issues: reviewing the related supplementary regulation of the labor law to ensure competitiveness of private companies; enforcing dispute settlement regulation on industrial relations properly to solve disputes quickly and fairly; promoting social systems (vocational training, job placement and a national certification system) to create a fair, flexible and productive labor market; simplifying the procedure to obtain business visas for expatriates to facilitate business activities; and establishing a practical social security program. ${ }^{7}$

The infrastructure related section covers the following: enacting a regulatory and policy reform to encourage private investment; making a concrete national plan; having an intensive communication with investors and other stakeholders; improving the infrastructure to promote investment; facilitating the implementation of existing power plant projects; completing the Jakarta outer ring road; rebuilding roads and highways. 8

The strategic investment action plan on Competitiveness of Small and Medium Enterprises ("SMEs") focused on strengthening the investment agency's role of providing service to investors; protecting the intellectual property rights in the domestic

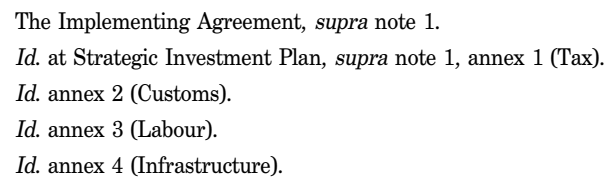


market; introduce and adopt of international industrial standard; and internalizing the understanding of EPA by the public.

\section{E. Some Anticipated Issues Constraining the Implementation of JIEPA}

\section{a. Ratification}

The different ratification instrument applied by two countries is a critical issue regarding the implementation of JIEPA. Indonesia ratified JIEPA with Presidential Regulation No. 36 of 2008 without prior approval from the Parliament, while, Japan ratified it through its parliament's approval. The question is whether the different of ratification instrument may affect the domestic implementation of JIEPA.

Article 9, paragraph 2 of Law No. 24 of 2000 concerning the international agreement states that the ratification of international agreements can be conducted by Law or Presidential Decree. Furthermore, Article 10 of the law states that the ratification of international agreements shall be conducted by law when dealing with strategic and very important affairs as follows: political issues; peace; defense and security of the State; change of region or change of the determination of boundaries of the Republic of Indonesia; sovereignty or sovereign state rights; human rights and environment; formation of new regulation, loan and or foreign grants. Meanwhile, ratification of agreements beyond the scope as referred to in this article can be conducted by a Presidential Decree. A copy of the Presidential Decree ratifying an international agreement shall be submitted to the House of Representatives to be evaluated. ${ }^{9}$

Pursuant to Articles 9, 10 and 11 of the same law, there is no distinction regarding the legal consequences or validity between international agreements ratified by Law and those ratified by Presidential Decree. Although JIEPA was ratified by Indonesia in the form of a Presidential Decree, the validity as well as its legal force is the same as agreements ratified by law - the only difference being the ratification procedure.

\section{b. Reviewing Mechanism through the Constitutional Court}

If a law violates the 1945 Constitution (as amended four times), 10 it is open to review or even revoke by submitting a petition to the Constitutional Court.11 The Constitutional Court, based on majority vote, shall decide whether certain laws violate provisions of

9 Law No. 24 of 2000 on International Agreement art. 10.

10 The 1945 Constitution was formalized one day after Declaration of Independence on August 17, 1945. Since President Suharto stepped down from power in 1998, the 1945 Constitution has been amended four (4) times by the Peoples Consultative Assembly in order to accommodate the protection of human rights, to limit Presidential terms, to decentralize the government and to increase the budget for education spending, among others.

11 Law No.24 of 2003 on Constitutional Court art. 10(1). 
the Constitution. If the Court finds any violation, such law shall be revoked or revised.

In accordance with Article 10, paragraph 1 of Law No. 24 of 2003, the Constitutional Court shall have the authority to: adjudicate whether certain provisions are unconstitutional; settle conflicts between competence of state institutions; dissolve political parties; and resolve general election disputes.

With respect to investment, the mechanism used to review the law could create legal uncertainty. Some incentives offered investors in accordance with the investment law can be revoked in case such provisions are found unconstitutional. A noticeable example is a decision where the Constitutional Court revoked provision granting automatic extensions to investor's land titles per Law No. 25 of 2007 concerning Capital Investment. 12 Other examples are the cancellation of Law on Electricity and cancellation provisions of certain articles of Law No. 22 of 2001 concerning Oil and Gas.13

\section{c. Legal Certainty for Investors}

Legal certainty is very crucial in every investment as it creates business certainty. Investors can carefully calculate investment benefits and risks before investing. Without legal certainty, investment risks will be higher and not predictable.

In order to promote legal certainty, it is important for the capital importing country (i.e., the host country) to have a strong commitment and consistency based on an effective legal system. The legal certainty for investment may create a more stable environment suitable to different situations, such as contract enforcement, acquired rights of the aliens, continuation of business activities, a dispute resolution mechanism, and law enforcement.

\section{d. Continuation of Business Activities}

The continuation of business activities should be absolutely guaranteed for investors. Frequent changes of national laws and regulations have detrimental effects on the legitimate rights of investors, both foreign and domestic.

\section{e. Pharamaceautical Business}

Another regulatory problem for foreign investment is the Decree of Ministry of Health No. 1010 of 2008 concerning Drug Registration. This ministerial decree has a negative impact toward the continuation of business activities currently conducted by both domestic and foreign-based pharmaceutical companies. Under the new regulation, only

\footnotetext{
12 Law No. 25 of 2007 concerning Automatic Extension of Land Rights art. 22. See also Decision of Constitutional Court No. 21-22/PUU/V/2007 (Mar. 17, 2008).

13 E.g., Law No. 22 of 2001 arts. 12 (3), 22 (1) and 28 (2) \& (3).
} 
pharmaceutical companies operating production facilities in Indonesia may acquire drug registration. It means that only such a company may sell its products in Indonesia. Existing pharmaceutical companies which do not have any such facilities could neither register, nor sell the products of the company. Such a regulation clearly creates a disastrous situation to pharmaceutical companies without production facilities in Indonesia, even though these companies have already existed and invested substantial amounts of money in research, facilities, and human capital. This regulation creates a bad precedent for the investment climate in Indonesia; consequently, it may cause the relocation of business, termination of activities, and capital outflow to other importing countries offering better treatment of pharmaceutical companies.

\section{f. Termination of Business Activities}

Capital will flow to countries offering the best investment climates. Today, nationalism is not a fundamental barrier to capital investment. There are many factors that contribute to a better investment climate, among others: tax and non-tax incentives, land titles, labor productivity, legal certainty, and ease of forming and terminating business entities.

The facts have shown that foreign investors have to spend more time and initial costs to open and terminate businesses in Indonesia. This issue should be properly addressed by Indonesia as a way to support the implementation of JIEPA. The approach shall be both from the level of law and policymaking to its implementation.

\section{Some Critical Anyalysis to the Existing Foreign Invesment Related Laws in Indonesia}

\section{A. Law No. 25 of 2007 concernig Capital Investment}

\section{a. The Underlying Policies}

Some policies underlying Law No. 25 of 2007 are reflected in the Presidential Instruction No. 3 of 2006 concerning Policy Package on Improvement Investment Climate which emphasizes the need to improve the investment climate in order to enhance economic growth. The appendix of this instruction elaborates five aspects, 19 policies, 85 action plans, which are equipped with outputs, a time frame, and the individual responsibility.14 This Presidential Instruction, of course, signified the seriousness of the Indonesian Government to improve the investment climate in Indonesia.

14 For further analysis of Presidential Instruction No. 3 of 2006, see Tulus Tambunan, Investment Climate in Indonesia: Issues, Challenges and Potential, KAdin Indonesiam-JETRO (2006); See also M. Ichsan Modjo, Implementation Package of Investment Policy, JAWA Pos NEWSPAPER, Mar. 13, 2006. 
Furthermore, in order to support the implementation of Law No. 25 of 2007, the President issued Presidential Instruction No. 5 of 2008 concerning the Focus of Economic Program for the year of 2008-2009. This Instruction is essentially seeking to increase national economic growth, preserve natural resources, increase energy efficiency, and improve environmental standards. The dictum in the Presidential Instruction has also emphasized that these steps are to be guided by the program covering improvements of the investment climate, macro-economic, infrastructure, and empowerment of small and medium-sized businesses.

\section{b. Main Provisions}

Law No. 25 of 2007 concerning Capital Investment mainly provides the same treatment to both foreign capital investment ("PMA") and domestic capital investment ("PMDN") by taking into account national interest. The government can nationalize or expropriate capital and/or property ownership of investors, only in accordance with law. 15 The rights of investors to transfer their assets to any party or to repatriate in foreign currency their capital, profits, royalties or dividends shall be guaranteed. All fields of business are basically open for investment. In some business meetings certain conditions are expected; the government provides title of rights with a longer period of validity. Provide immigration services, licenses, and/or facilities following the recommendation of the Investment from Investment Coordinating Board ("BKPM"); BKPM is chaired by a head directly responsible to the President. 16

\section{c. New Provisions to Attract Capital Investment}

Law No. 25 of 2007 offers some new provisions to attract investment. The period given to the rights of the land has been extended. Regulations regarding the use of foreign employees have become more flexible. Special incentives for certain investment activities, including for 'pioneer status' and special economic regions are provided.17

\section{d. Promoting Small and Medium Enterprise and Pioneer Industry}

Law No. 25 of 2007 offers some incentives to investment that involve participation of SMEs. There are also some incentives for specific investments, such as investment for emerging industries and industries in need of labor. 18 


\section{e. Deficiencies and Shortcomings}

Some provisions on land rights like automatic extension of land rights are not applicable as they are not synchronous with other laws like Law No. 5 of 1960 on Agrarian Law. There are perceptions that Law No. 25 of 2007 provides more protection and accommodates the interest of the foreign investor without proper protection to local corporate investors. In some cases, Law No. 25 of 2007 would reflect a setback akin to previous investment laws, especially on the provisions related to transfer of technology, the use of foreign employees, obligations on divestment, etc.

\section{f. Implementing Regulations}

Law No. 25 of 2007 is elaborated into several implementing and operational regulations such as: Presidential Regulation No. 76 of 2007 on Criteria and Requirements of Field of Business that is Closed for investment and Open for Investment subject to certain conditions; Presidential Regulation No. 77 of 2007 on List of field of Business that is Closed and Open for Investment subject to certain Conditions as modified by Presidential Regulation No. 111 of 2007 and later on amended by Presidential Regulation No. 36 of 2010; and Presidential Regulation No. 90 of 2007 on the Investment Coordinating Board.

In addition, there are some other regulations promoting investment climate, including Government Regulation No. 1 of 2007 as amended by Government Regulation No. 62 of 2008 concerning Income Tax Facilities for Investment in the Field of Specific Business and/at the Specific Region or Area; Government Regulation No. 45 of 2008 concerning the Guidelines of Granting Incentive and Facilitate Investment Activities in the Region.

\section{B. Law No. 13 of 2003 on Manpower}

Law No. 13 of 2003 on Manpower was adopted in order to create working convenience and industrial peace in the workplace. A conducive and peaceful working environment can only be achieved when it is assured by the following three conditions: (a) labor protection through insurance; (b) the insurance business tranquility; and (c) the implementation of security and democracy in the workplace. 19

Law No. 13 of 2003 was designed to accommodate the interest of both employer and employee. From the standpoint of investor (employer), however, this law provides too much protection to labor interests, while putting onerous obligations on the employer. Meanwhile, from the perspective of labor (the employees) this law is perceived as

19 Aloysius Uwiyono, The Implications of Manpower Law No. 13 of 2003 on Investment Climate, 22 BUS. L. J. 5, 9-16 (2003). 
providing more benefits to employers that would become disadvantages for labor, e.g., issues relating to outsourcing and the use of subcontractors. 20

The revision of Law No. 13 of 2003 on Manpower is deemed as urgent due to the following reasons. First, some legal provisions are inconsistent. Second, some articles are found incorrect and confusing in their formulation. Third, the law is still based on the paradigm of employer-employee conflict and not based on principle of partnership between employer and employee. 21

\section{Law No. 40 of 2007 concerning Limited Liability Companies}

Law No. 40 of 2007 concerning Limited Liability Companies creates some controversy, especially provision concerning legal obligations for Corporate Social Resposibility ("CSR"). In addition, this law requires such a high minimum capital that the costs of doing business may increase. Consequently, the initial start-up cost becomes higher. ${ }^{22}$

\section{Law No. 37 of 2004 concerning Bankruptcy and Suspensions of Debt Payment Obligations}

Law No. 37 of 2004 does not provide for a simple evidentiary system. Petition of bankruptcy declaration is not effective as means for foreign creditor to recover its claim from debtor. Suspension of debt payment obligations is not yet the effective tool for corporate solvency. 23

\section{E. Law No. 32 of 2004 concerning Regional Administration}

Law No. 32 of 2004 as the amended version of the previous Law, namely Law No. 22 of 1999 still contains some confusing provisions. One example is a provision jurisdiction of state affairs between the Central Government and Regional/Local Government,24 which are still not clear and may cause legal uncertainty to investors.

\footnotetext{
20 The issue of outsourcing and subcontracting works has become hot and sensitive issues for the revision of Law No. 13 on Manpower.

21 Uwiyono, supra note 19.

22 In previous Company Law (Law No. 1 of 1995) the minimum cost for establishing a company is only Rp 20 million which is equal with US \$200,000, while under the new Company Law (Law No. 40 of 2007) the minimum cost has been raised to Rp 50 million or equal with US \$500,000.

23 Lastuti Abubakar, Some Legal Issues Concerning Bankruptcy Law in the Context of Direct Investment in Indonesia (2009) (Joint research paper between JICA-Indonesia and Center for Regulatory Research).

24 Government Regulation No. 38 of 2007 concerning Division of Administrative Affairs between Central Government and Local Government.
} 


\section{Comparative Analysis among JIEPA Provisions, Foreign Investment Laws in Indonesia and International Standards}

\section{A. Protection and Guarantee on Foreign Investment}

a. Under the framework of JIEPA, provisions on protection and guarantee on foreign investment can be found at Chapter 5, particularly in the following provisions: (1) National Treatment;25 (2) Most Favored Nation Treatment;26 (3) General Treatment;27 (4) Prohibition of Performance Requirements;28 (5) Expropriation and Compensation;29 (6) Protection from Strife; 30 and (7) Transfers. 31

b. Law No. 25 of 2007 concerning Capital Investment offers certain protection and guarantees to investment, such as: (1) Equal Treatment to Investors;32 (2) Protection from Nationalization and Expropriation;33 (3) Transfers of Capital and Profit Remmitance; 34 and (4) Protect and Guarantee the Rights of Investors. 35

c. International Standards on Protection of Foreign Investment against Expropriation and Nationalization are as follows. First, nationalization and expropriations are traditionally based upon the physical taking of property. 36 Second, an important development has been the extension of the concept of protected property to contractual rights. 37 Third, more recent developments have shifted the focus from direct takings to individual takings of foreign property. Fourth, some cases are qualified as 'creeping expropriation' or disguised expropriation involving, e.g, the forced divestment of shares of a company, interference with the rights of management, appointment of managers, refusal to grant access to labor or raw materials, and excessive or arbitrary taxation. 38 Fifth, regulatory taking (in grey areas) is to take property falling within the police powers of the host country or the regulations concerning the environment, public health, morals, culture or the

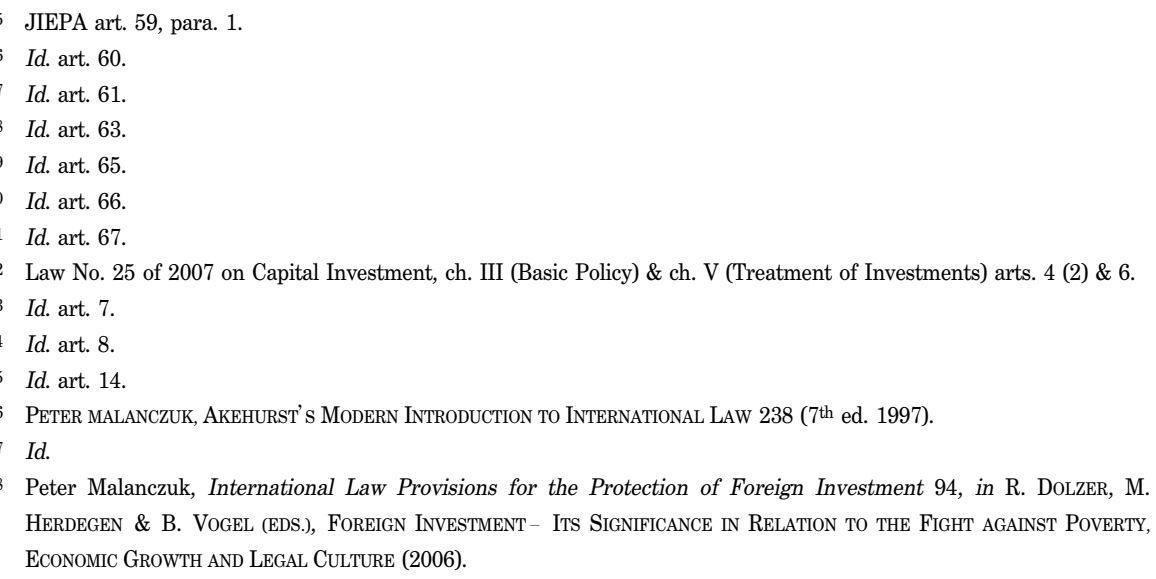
Herdegen \& B. Vogel (eds.), Foreign Investment - Its Significance in Relation to the Fight against Poverty, ECONOMIC GROWTH AND LEGAL CULTURE (2006). 
economy of the host-country. The problem is how to distinguish "justified' and 'unjustified' regulatory takings. 39

\section{B. Protection of Acquired Rights of Investors}

a. JIEPA

Within the framework of JIEPA, protection of the acquired rights of aliens shall cover certain possible situations caused by a host country's act such as expropriation, nationalization, and confiscation, prohibition of transfer of capital and/or profits, revocation of certain licenses, or property/assets. 40

b. Indonesian Domestic Law

Basically, Law No. 25 of 2007 concerning Capital Investment provides some protections to the acquired rights of aliens as long as they are not against Indonesia's supreme national interest. 41

\section{c. International Concerns}

Most capital exporting countries are concerned about measures taken by host states that would be seriously harmful to the foreign investor' s interests such as tax discrimination, abuse of intellectual property rights, arbitrary refusal to grant licenses, bars to the transfer abroad of funds (capital, royalty, profits, etc.) by the investor, bars to the option of investor to employ foreign managerial or specialized staff from abroad.

\section{Implementation of Minimum Standards of Treatment to Foreign Investors}

\section{A. National Standards}

Many developing countries have maintained a traditional approach that employee compensation should be determined by domestic law. 42 The position of developing countries is based on two main documents: the UN General Assembly Resolution 1803 on the Permanent Sovereignty over Natural Resources, 43 and the Charter of Economic Rights and Duties of States. 44

\footnotetext{
9 For more clarification, see R. Dolzer, Indirect Expropriations: New Developments, 11 N.Y.U. ENVTL. L. J. 64 (2002).

JIEPA on Investment ch. 5, arts. 65-67.

1 Law No. 25 of 2007 on Capital Investment arts. 7-8.

2 Dolzer, supra note 39, at 108. See also FV Garcia-Amador, Calvo Doctrine, Calvo Clause, I EPIL I 521 (1992).

3 G.A. Res. 1803(XVII), U.N. GAOR Supp. (No. 17), at 15, U.N. Doc. A/5217 (Dec. 14, 1962).

44 G.A. Res. 3281, U.N. GAOR, 29th Sess., Supp. No. 31, U.N. Doc. A/9631 (Dec. 12, 1974).
} 
The former Soviet Union maintained the principle of national treatment to justify the refusal to compensate aliens. The term 'nationalization' was introduced to emphasize the role of taking property in the interest of the community, instead of focusing on the effect of the expropriation for the owner of the property. 45

\section{B. International Minimum Standard}

Most capital exporting countries are in favor of establishing international minimum standards for the protection of investors. The minimum standards shall cover the following sources:46

a. Measures for the protection of foreigners and their property;

b. Rules of international responsibility of the host state for internationally wrongful acts;

c. Diplomatic protection by the home state of the foreign's nationality;

d. Lawful taking of foreign property for a public purpose with non-discriminatory compensation; 47

e. Some terminologies commonly used with those meaning as 'market value,' "fair market value," 'just compensation,' 'effectively realizable,' 'without unreasonably delay," "the value immediately before the 'compensation,' and 'full compensation"; and

f. The NAFTA provisions on expropriation and compensation 48 paraphrase the Hull standard while referring to fair market value.

\section{Investment Risks in Indonesia}

\section{A. Investment Risk Classification}

Each investment activity always poses potential risk. The problem lies in to what extent the ability to identify and manage the risk, so that risks may be more predictable.

In general, the risk in investment activities such as infrastructure-setting can be divided into "typical global risk" and "typical elemental risk." 49 There are also

45 Malanczuk, supra note 38 , at 98 .

46 Id.

47 Formula Hull refers to a declaration made by the Minister of Foreign Affairs U.S. Codell Hull in 1930 in his correspondent with the Government of Mexico after the Mexican's expropriation to US's oil interests. According to Hull Formula, "[n]o government is entitled to expropriate private property for whatever purpose without provision for prompt, adequate and effective payment therefore." For details, see Malanczuk, supra note 38, at 96-98.

48 The following are legal measures related to the Hull Formula: Article 1110 of NAFTA provisions on expropriation and compensation; the Energy Charter Treaty; and the APEC Non-Binding Investment Principles of 1994. Also, the World Bank Guidelines on the Treatment of Foreign Investment refer to the term 'appropriate compensation,' but define this standard in a manner that is equivalent to the Hull formula.

49 On the various risks, see A. Merna \& N.J. Smith, Guide to the Preparation and Evaluation of Butld, Own, Operate, Transfer Project Tenders (2d ed. 1996). 
commercial risks and non-commercial risks. "Non-commercial risks" are generally regarded as: currency transfer, expropriation, breach of contract, war and civil disturbances. 50

In addition, the parties can extend the scope of "non-commercial risks" based on mutual consent. The "typical global risk" includes political, legal, commercial, and environmental risks. The "typical elemental risk" includes construction, operating, financial, and revenue risk. 51

Political risks are normally associated with the conditions, policies and/or action of the host country such as stability, expropriation, nationalization, forced sales of assets, the price/tariff, changes in the agreement, increase tax and royalty, the addition of duties, repatriation dividends, change of government, external stability, changes in fiscal policy, debt ratings of the State, and infrastructure improvement. 52 Risk aspects related to the concession can occur in various situations such as delays in the provision of concessions, the concession period, the determination of tariff by principal, the questions by public, related legislation, commitment to the concession contract, concession exclusivity and competition from existing facilities. 53

Legal risks are usually associated with conditions in the host country such as legal framework, changes in laws during the concessions period, conflict with local community, changes in import-export laws and regulations changes of corporate law, changes to the standard and specification, applicable law on trade, liability issues, ownership, etc. Legal risk may also arise from such situations as the concession contract type, the change of the rights and obligations on the basis of the applicable legal framework, changes in contract provisions, and the imposition of certain laws on the concessions and the settlement of disputes. Market aspects may also raise the legal risk in cases such as changing the facility, or the price escalation of raw materials and consumables, economic downturns, product quality, competition, receiving the public on payment system policy, consumer resistance and the like. 54 
Commercial risks are often in line with the availability of raw materials, currency exchange rates, interest rate fluctuations, and currency devaluation.55 Environmental risks would maintain several aspects such as project location, existing environmental constraints, and the impending environmental changes. The influence of environmental risks can be divided into those categories as the press re-groups the external factors toward the operation, environmental impact, and the influence of environmental regulatory approval. Environmental risk may be also caused by the occurrence of ecological changes during the period of concession. 56

Aspects of "typical elemental risk" will not be elaborated as it is specifically related to the development and operation of infrastructure projects. In general, the amount of risk would be described as construction risks influenced by physical aspects, construction, design and technology. These operations are strongly influenced by conditions, maintenance and training. Financial risk is usually related to the interest rate, repayment, loans, and equity, while the revenue risk is involved in the needs, the price/tariff, and current development of the country. 57

\section{B. Protection on "Non-Commercial Risks" under International Law}

The Multilateral Investment Guarantee Agency ("MIGA") plays a very important role in encouraging and protecting foreign investment with the "non-commercial risks." 58 Other activities conducted by MIGA include research, investment promotion, information, investment opportunities, assistance provision and technical advice.59 The MIGA also encourages member countries to conclude agreements on the protection and guarantee of investment. The MIGA Convention provides dispute resolution mechanisms such as negotiation, conciliation, and arbitration. 60 When one of those mechanisms fails to resolve the dispute, the dispute can be submitted to the International Center for Settlement of Investment disputes ("ICSID").

Investors from the MIGA member countries shall acquire protection and guarantee for their "non-commercial risk." Investment protection and guarantee on currency transfer may usually arise along with the policies or the determination of the host country to limit the transfer of currency to other countries or to be received by other insured parties. The currency transfer risk includes the failure of local government to act

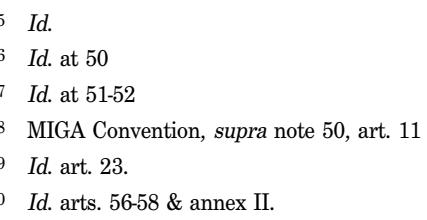


within a reasonable time. 61

The risk of "expropriation and similar measures" may be due to an action by the lawmaker or the host-country's administrative action. When the host country does not undertake the obligation, it would cause loss to securities holders. 62

Contract risks occur when the government violates an agreement with the investor and the investor cannot seek recourse in courts or arbitration. Such a risk may be also caused by lack of decision concerning the settlement of disputes. Additionally, decisions somethimes can not be implemented. Meanwhile, there is a risk due to military actions or civil unrest. 63

The risk of 'eligible investments' means the equity interest including loans and long-term or medium-term guarantee for equity holders in the company, and forms of direct investment as determined by the MIGA Board. In the majority decision of the MIGA Board, the eligible investment may be expanded.64

\section{Protection and Guarantee of "Non-Commercial Risks" Investment Activities in Indonesia}

As a member State of the MIGA Convention, Indonesia is observing the provisions of investment guarantee and protection, especially concerning "non-commercial risks." However, Indonesia should try to develop principles and mechanisms concerning guarantees and protection for non-commercial risks at the global level.

\section{Dispute Settlement Mechanism}

\section{A. Sources of Disputes}

Foreign direct investment activities require effective, efficient, fair and impartial dispute resolution mechanisms. Such an ideal condition may promote legal certainty and predictability of foreign direct investment. It would also reduce country risk. An ideal dispute resolution mechanism shall be developed both at the international and national level. 65

The FDI disputes may be caused by those sources as policy of the host country, violation of obligations by the host-country (capital importing State) or home-country

61 Rajagukguk, supra note 50, at 29.

62 Achmad Yulianto, The Role of Multilateral Investment Guarantee Agency (MIGA) in Investment Activities, 22 Bus. L. J. 5, 42 (2003).

63 Id.

$64 \quad$ Id. at 30

65 The author is of the opinion that an ideal dispute resolution mechanism on direct investment related cases shall be developed based on the harmonization between domestic and international law, especially to guarantee its enforcement. 
(capital exporting State), the foreign investor or counter-part in the host-country, the local community, or weaknesses in law enforcement.66

Some policies of host countries may cause investment related disputes such as fiscal, foreign debt, currency, agrarian, ownership, state's asset management, labor, trade and industry, state administration, SMEs, and public service. The host country sometimes fails to provide equal treatment with an effective and fair dispute resolution mechanism, protect acquired rights of aliens, contractual rights of investors, and investors against expropriation and confiscation. The home country also fails to respect human rights, environment and democracy of the host-country. In some cases, the foreign investor fails to comply with laws and regulations of the host country as well as international legal instruments, which may lead to disputes. Breach of contract, expropriation of assets, and forced take-over of shares conducted by counter-part of host country or local communities may potentially cause disputes. Furthermore, weaknesses in contract enforcement, ineffective and unfair dispute settlement mechanism and complicated law enforcement mechanism may also lead to disputes. 67

\section{B. Parties to the Disputes}

Parties to the disputes may be as follows: (a)State-State; (b)Investor-State; (c) Foreign Investor-Counterpart from Host-Country; and (d) Investor- Local Community.

\section{Dispute Resolution Mechanism under International Investment Law}

\section{a. State-State Disputes}

The disputes between States concerning investment under JIEPA can alternatively be settled by diplomatic channels (negotiation, consultation enquiries, good offices, mediation, conciliation), 68 the Permanent Court of Arbitration, the International Court of Justice, and the WTO Dispute Settlement Understanding. 69

\section{b. Investor-State Disputes}

Disputes between the host state and foreign investors can be settled through amicable settlement, ICSID, MIGA, and in national courts.70

\footnotetext{
66 For further exploration of the dispute settlement mechanism in the foreign direct investment ("FDI") in Indonesia, see I.B.R. Supancana, Dispute Settlement Mechanism on Foreign Direct Investment in Indonesia (The international seminar on FDI from the Perspective of International Investment Law, Jakarta, Indonesia, Apr. 1, 2008).

67 For further information, see M. SORNARAJAH, The INTERNATIONAL LAW ON FoREIGN INVESTMENT 344-366 (2d ed. 2004).

68 U.N. Charter art. 33, para.1

69 UNCTAD, Dispute Settlement: State-STate, UNCTAD SERIES on Issues In Intgernational Investment AgreEmentS (2003). See also Provisions on Settlement of Disputes under the Framework of JIEPA arts. 138-146.

70 For further detail, see UNCTAD, id.
} 


\section{c. Investor-Investor Disputes}

Disputes between investors can be resolved through amicable settlement, the International Chamber of Commerce ("ICC"), Alternative Dispute Resolution (“ADR"), the United Nations Commission on International Trade Law ("UNCITRAL"), a national arbitration body, or the national courts.

\section{d. Investor-Local Community Disputes}

Disputes between investors and local companies can be resolved through amicable settlement, arbitration, or the national courts.

\section{Legal Framework of Investment Related Dispute Settlement Mechanism under Indonesian Law}

\section{a. Law No. 25 of 2007 concerning Capital Investment}

Article 32 of Law No. 25 of 2007 provides for a dispute settlement mechanism. The investment dispute settlement provision in this article is very general and only covers disputes between the government and investors. Under Article 32 of Law No. 25 of 2007, disputes can be settled through negotiation to reach an acceptable solution, arbitration, available ADR, or courts in accordance with relevant laws and regulations. Disputes between the government and local investors shall be settled through arbitration if the parties so agreed. In the case when the parties do not agree to settle the dispute via arbitration, the disputes shall be transferred to court proceedings. 71

\section{b. Law No. 30 of 1999 concerning Arbitration and ADR}

Law No. 30 of 1999 contains comprehensive regulations on dispute settlement through arbitration. This law does not, however, have ADR provisions except for Article 6 which merely mentions mediation. Some important provisions on arbitration are appointment of arbiters, rules and procedures on arbitration, opinion and decision by arbitration tribunals, and annulment of arbitration awards. Other important provisions include recognition and enforcement of both foreign and domestic arbitral award.72

\section{Law No. 7 of 1994 concerning Ratification of the WTO Agreement of 1994} Law No. 7 of 1994 includes Annex on Trade Related Investment Measures ("TRIMS") and Dispute Settlement Understanding ("DSU"). By ratifying the WTO Agreement, Indonesia is also bound by provisions on settlement of disputes as formulated in DSU

71 Law No. 25 of 2007 on Capital Investment art. 32.

72 Law No. 30 of 1999 on Arbitration and ADR arts. 59-69. 
through its Disputes Settlement Body ("DSB"). The provisions shall also apply to TRIMS.

d. Law No. 5 of 1968 concerning Ratification of Convention on the Settlement of Disputes between States and Nationals of Other States

The Convention on the Settlement of Disputes between State and Nationals of Other States was initiated by executive directors of the International Bank for Reconstruction and Development ("IBRD"). Until 2002, 136 States ratified it. Under the framework of the Convention, the ICSID has been established. The ICSID provides facilities and a mechanism for settlement of investment disputes between States and nationals of other States via the process of arbitration or conciliation.73 The provisions of the ICSID include administrative and financial regulations, institutional rules, conciliation rules and arbitration rules. The decision of the ICSID shall be final and binding upon the parties and all contracting parties to the Convention shall recognize and enforce the ICSID's decision with good faith. ${ }^{74}$

\section{e. Law No. 4 of 2004 concerning Judiciary Power}

Law No. 4 provides independency to judicial authority for administrating judiciary power for the purposes of upholding law and justice. 75

\section{f. Law No. 14 of 1985 as Amended by Law No. 5 of 2004 concerning the Supreme} Court

The Supreme Court is the highest judicial body for all matters decided by adjudicative process except for matters decided by the Constitutional Court, certain disputes decided by the Industrial Relation Court, and disputes over jurisdiction to adjudicate between District Courts in jurisdictional territory of one High Court.76

\section{g. Law No. 8 of 2004 concerning the General Judicial System}

National courts are divided into District Courts, High Courts, and the Supreme Court. District Court is empowered to examine, decide and settle criminal and civil cases in first instance. High Courts are civil and criminal courts of first appeal.

Special court are as follows: the Constitutional Court (Law No. 24 of 2003); the Administrative Court (Law No. 5 of 1986 as amended by Law No. 9 of 2004); the

\footnotetext{
73 For Arbitration Process, see ICSID Convention arts. 36-55. For Conciliation, see ICSID Convention arts. 28-35.

74 ICSID Convention arts. 53-55.

75 Independency of Judiciary Power is guaranted by Article 24 (1) of 1945 Constitution.

76 Article $24 \mathrm{C}$ of the 1945 Constitution as has been amended, and Article 2 of Law No. 14 of 1985 as amended by Law No. 5 of 2004 concerning the Supreme Court.
} 
Commercial Court (Law No. 37 of 2004); the Tax Court (Law No. 14 of 2002); the Religious Court ( Law No. 7 of 1989 as amended by Law No. 3 of 2006); the Children's Court (Law No. 3 of 1997); the Military Court (Law No. 31 of 1997); the Industrial Relations Court (Law No. 2 of 2004); the Court of Fishery Affairs (Law No. 31 of 2004); the Criminal Corruption Court (Law No. 30 of 2002); the Human Rights Court (Law No. 26 of 2000); and the Islamic Syariah Court (Law No. 11 of 2006).

\section{h. Presidential Decree No. 31 of 1986 concerning Ratification of the Convention Establishing the MIGA}

In accordance with the MIGA Convention of 1985, MIGA acts as mediator offering several services such as guaranteeing the project against non-commercial risk, providing good offices, and helping the host country to promote its investment climate. The MIGA guarantees non-commercial risk such as prohibition or limitation of transfer (currency measures), expropriation and similar measures, war and civil disturbances, breach of contracts, etc.77 When conducting its functions, MIGA considers not only country risk, but also project risk. MIGA also encourages its member countries to conclude agreements regarding the protection and guarantee of investment. Other activities of MIGA include research, investment promotion, information provision on investment opportunities, and technical advice and assistance. 78

\section{i. Presidential Decree No. 34 of 1981 concerning Ratification of the Convention on the Recognition and Enforcement of Foreign Arbitral Awards}

The Convention on the Recognition and Enforcement of Foreign arbitral awards shall apply to foreign arbitral awards by arbitration panels outside the country where the decision will be recognized and enforced. It covers decisions by both permanent and adhoc arbitration tribunals. ${ }^{79}$ The scope of decision shall be in commercial field. A state may refuse to recognize and enforce foreign arbitral award as long as the following conditions are met: invalid or illegitimate arbitration agreement; improper notification regarding the appointment of arbiters; the tribunal exceeds its power; corruption and serious violations of existing laws; and lacks of goods consideration as a legal basis for the award. 80

j. The Regulation of the Supreme Court No. 1 of 1990 concerning Procedures for the Enforcement of Foreign Arbitral Awards

The Regulation of the Supreme Court No. 1 of 1990 was issued as the consequence of

\footnotetext{
7 On Covered Risk, see MIGA Convention, supra note 50, art. 11.

8 Id. art. 23

9 Convention on Recognition and Enforcement of Foreign Arbitral Award arts. I, para 2 \& III (1958).

80 Id. art. v, paras. 1 (a)-(e).
} 
ratification of the Convention on the Recognition and Enforcement of Foreign Arbitral Awards. The Regulation provides the courts with competence to enforce foreign arbitral awards, criteria of foreign arbitral awards, foreign arbitral award that can be recognized and enforced, the Supreme Court's competences to issue 'execuatur,' required procedures for exequatur's application, confiscation procedures, and cost.

\section{k. The Regulation of the Supreme Court No. 1 of 2008 concerning Court-Annex Mediation Procedures}

The Regulation of the Supreme Court No. 1 of 2008 was adopted to integrate mediation with court proceedings, which would be effective in reducing the number of cases at the Supreme Court and to provide a quicker and cheaper dispute settlement mechanism to the parties. 81 This regulation contains important mediation procedures for courts including general guidelines, pre-mediation and mediation-stage rules, venue, cost and the like.82 One of the important provisions in this regulation is the obligation that all cases in the district court should be first settled amicably through the assistance of mediator(s). Mediators can be appointed from professional mediators or judges at relevant courts in a neutral and impartial manner. 83

\section{Concluding Remarks and Suggestions}

\section{A. Concluding Remarks}

Comparing JIEPA with Indonesian foreign investment laws and priciples of international law, some conclusions can be drawn:

The JIEPA is one of the most comprehensive bilateral economic cooperation agreements covering a wide range of economic cooperation. The JIEPA is elaborative and even complemented with strategic investment action plans having clear targets. The principles as contained in the agreement are reflective of existing international standards.

The Indonesian laws related to foreign investment cover not only the direct investment, but also other relevant aspects of investment such as labor, corporate law, regional autonomy, bankruptcy, etc. The government is also trying to improve the investment climate through its policies. Nonetheless, some investment provisions still contain deficiencies and shortcomings.

There are some unfavorable situations of the Indonesian legal system for the implementation of JIEPA. Among others the different ratification instruments between

\footnotetext{
Consideration b of Regulation of the Supreme Court No.1 of 2008 concerning Court-Annexed Mediation Procedures.

82 Regulation of the Supreme Court No. 1 of 2008 concerning Court-Annexed Mediation Procedures arts. 7-23.

83 Id. arts. 8-9
} 
Indonesia and Japan may create uncertainty on the implementation of JIEPA; the frequent changes in regulation in Indonesia will lead to business uncertainty and be harmful its sustainability; the relative difficulty in terminating a business under Indonesian law.

Regarding the protection of investor rights, there are some discrepancies on the following subjects. First, JIEPA contains a wider range of protection regulations compared to Indonesian investment laws. Second, the acquired rights under JIEPA are more elaborate than Indonesian investment law. Third, JIEPA is based on minimum international standards, while the Indonesian investment law (Law No. 25 of 2007) is mostly influenced by domestic standards.

There are some potential risks associated with investing in Indonesia, both typical global risk and elemental risk. The typical global risks include political, legal, commercial and environmental risk, while typical elemental risks include construction, operating, financial and revenue risk. As a contracting party to the MIGA Convention, Indonesia is observing the provision of guaranteeing non-commercial risk.

Compared to international standards, several observations can be made with regards to the dispute settlement mechanism. First, the investment dispute settlement mechanism has not been fully developed in Indonesia except for litigation, arbitration and mediation. Second, there are some procedural laws to settle each field of dispute. Third, the recognition and enforcement of foreign arbitral awards should be considered.

\section{B. Suggestions for the JIEPA and Its Implementation}

In order to improve the Indonesian investment climate and to support effective implementation of JIEPA, the following measures shall be taken. First, an in-depth study on JIEPA's provisions is necessary so that Indonesian laws and regulations can be adjusted to the JIEPA. Second, certain deficiencies and shortcomings should be followed-up and fixed. Third, potential constraints of the JIEPA should be scrutinized and considered in the implementation stages by its stakeholders. Fourth, some adjustment for relevant domestic laws and regulations should be carried out mainly concerning legal rights of investors such as application of minimum standards of treatment based on international practices, maximum protection to the acquired rights of investor, and extention of investment guarantee and protection. Fifth, investment dispute settlement mechanism must be improved for legal certainty for concluding its enforcement mechanism. Sixth, the Indonesian government should be more committed to remedy deficiencies and shortcomings to foster a better investment environment. Such attitude not only contributes to the improvement of Indonesian legal system, but also its global competitiveness. 